\title{
PENGARUH LETAK WADAH BUDIDAYA KURUNG DASAR DAN KURUNG LEPAS DASAR TERHADAP PERTUMBUHAN DAN KELULUSHIDUPAN KEPITING BAKAU (Scylla serrata)
}

\author{
Manggala Bintang Idatra, Sri Rejeki, Restiana Wisnu Ariyati \\ Departemen Akuakultur Fakultas Perikanan dan Ilmu Kelautan, Universitas Diponegoro
}

\begin{abstract}
ABSTRAK
Kepiting bakau (Scylla serrata) merupakan salah satu sumber daya perikanan bernilai ekonomis penting. Upaya produksi budidaya kepiting bakau sudah cukup lama dilakukan dan dikembangkan, tetapi masih terdapat beberapa permasalahan, salah satu permasalahan yang ada yaitu pada aspek penerapan metode pada wadah budidaya. Umumnya terdapat dua jenis sistem peletakkan wadah budidaya kepiting bakau ( $S$. serrata) yaitu letak wadah budidaya pen culture (kurung dasar) dan karamba apung (kurung lepas dasar), namun dari kedua jenis sistem peletakkan wadah tersebut belum diketahui yang sifatnya memberikan optimalisasi dan stabilitas dalam aspek pertumbuhan dan sintasan. Tujuan dari penelitian ini adalah mengetahui pengaruh letak wadah budidaya kurung dasar dan kurung lepas dasar terhadap pertumbuhan dan kelulushidupan kepiting bakau ( $S$. serrata), serta mengetahui letak wadah budidaya yang terbaik untuk meningkatkan pertumbuhan dan kelulushidupan kepiting bakau (S. serrata). Penelitian ini menggunakan 2 perlakuan (perlakuan A= letak wadah budidaya kurung dasar, dan $\mathrm{B}=$ letak wadah budidaya kurung lepas dasar) dengan 6 pengulangan. Hewan uji yang digunakan adalah kepiting bakau (S. serrata) dengan bobot awal pemeliharaan \pm 80 g/ekor dengan padat penebaran 4 ekor $/ \mathrm{m}^{2}$. Penelitian dilaksanakan selama 30 hari (1 bulan) yaitu pada 18 Juni sampai 18 Juli 2017. Hasil penelitian menunjukkan bahwa perlakuan letak wadah budidaya kurung lepas dasar (perlakuan B) berpengaruh nyata (pvalue $<0,05$ ) terhadap bobot mutlak (rerata $\pm \mathrm{SD}=30,64 \pm 2,53 \mathrm{~g}$ ) dan pertumbuhan relatif (rerata $\pm \mathrm{SD}=1,28 \pm 0,19$ g), namun tidak berpengaruh nyata terhadap kelulushidupan kepiting bakau ( $S$. serrata). Kualitas air pada media pemeliharaan terdapat pada kisaran yang layak untuk pemeliharaan hewan uji.
\end{abstract}

Kata kunci: Kepiting Bakau (Scylla serrata), Wadah Budidaya, Pertumbuhan, Kelulushidupan.

\begin{abstract}
Mud crab (Scylla serrata) is high-valuable fishery commodity and preferable-food in the community. The production of mud crab is long enough to do and be developed, but there are still some problems, wich is the aspects of the application of cultivation methods. It is commonly known that mud crab culture impelements 2 kind of cage location settings, they are pen culture (bottom) and floating cage (off bottom), but there is lack of information for the suitable one.The purpose of this research is to know the influence of bottom cage and off bottom cage on growth and survival rate of mangrove crab ( $S$. serrata), and to know the best one of cultivation cage location to increase growth and survival rate of mud crab (S. serrata). This research applied 2 treatments (Treatment A was bottom cage and Treatment B was off bottom cage) with 6 replications. The initial weight average and culture density of mud crab was $80 \mathrm{~g} / \mathrm{ind}$ and $4 \mathrm{ind} / \mathrm{m}^{2}$. The study was conducted for 30 days $(1$ month) it is on 18 June to 18 July 2017. The result showed that Treatment B (off bottom cage) was significantly different $(\mathrm{P}<0,05)$ towards its absolute weight growth value $(30,64 \pm 2,53 \mathrm{~g})$ and relative growth rate $(1,28 \pm 0,19$ $\mathrm{g} /$ day) and yet it was not significantly different $(\mathrm{P}>0,05)$ with its survival rate value. The water quality of the mud crab culture was in recommended average value.
\end{abstract}

Keywords: Mud crab (Scylla serrata), Cage, Growth, Survival Rate. 


\section{PENDAHULUAN}

Kepiting bakau (Scylla serrata) merupakan salah satu sumber daya perikanan bernilai ekonomis tinggi dan potensial untuk dibudidayakan. Hal ini memberikan peluang pengembangan komoditas kepiting bakau secara lebih maju. Pemenuhan kebutuhan kepiting bakau melalui intensifikasi penangkapan secara besar-besaran akan mengakibatkan penurunan populasi bahkan kelangkaan kepiting bakau di alam, oleh karena itu perlu dilakukan usaha budidaya pembesaran kepiting bakau (S. serrata) secara intensif, sehingga dapat menghasilkan kepiting bakau yang berkesinambungan (Djunaedi et al., 2015). Menurut Rangka (2007), salah satu usaha untuk mengantisipasi kebutuhan benih kepiting adalah dengan usaha budidaya pembesaran. Upaya produksi kepiting bakau melalui kegiatan budidaya pembesaran sudah cukup lama dilakukan dan dikembangkan, tetapi hingga saat ini budidaya kepiting bakau belum memberikan hasil yang optimal, masih banyak permasalahan yang dihadapi dalam kegiatan budidaya pembesaran kepiting bakau. Teknologi dan wadah budidaya yang digunakan selama kegiatan budidaya pembesaran kepiting bakau (S. serrata) sangat beragam.

Umumnya terdapat dua jenis sistem peletakkan wadah budidaya kepiting bakau (S. serrata), yaitu letak wadah budidaya pen culture (kurung dasar) dan karamba apung (kurung lepas dasar). Budidaya sistem wadah budidaya pen culture merupakan sistem budidaya kepiting dengan prinsip pelekakkan kurung dasar, bentuk wadah berupa sekat pembatas yang ditancapkan mengelilingi lokasi budidaya, sekat tersebut ditancapkan menggunakan patok kayu dan jaring yang berfungsi agar kepiting yang dibudidayakan tidak dapat keluar dari wadah budidaya, sistem wadah budidaya ini memiliki kekurangan yaitu penurunan kualitas air pada media budidaya relatif cepat, dikarenakan oleh akumulasi dari sisa metabolisme kepiting yang ada pada lokasi budidaya selama pemeliharaan. Budidaya kepiting bakau dapat juga dilakukan menggunakan sistem wadah budidaya kurung lepas dasar berupa karamba apung. Karamba apung dapat dibuat dari bambu atau keranjang plastik (basket) yang dipasang pada kolom perairan, karamba tersebut dapat dipasang menggunakan patok penyangga maupun dengan diberikan pelampung sehingga wadah budidaya tetap berada pada kolom 
perairan. Kekurangan dari sistem budidaya ini adalah tingginya modal yang harus dikeluarkan untuk membuat karamba atau untuk membeli basket kepiting bakau. Berdasarkan kedua jenis sistem peletakkan wadah tersebut belum diketahui yang dapat meningkatkan pertumbuhan dan kelulushidupan. Menurut Djunaedi et al. (2015), karamba apung digunakan oleh pembudidaya untuk pembesaran kepiting. Karamba dibuat dari bilah bambu yang disusun dan dibuat kotak, pada sisi panjang yang bersebelahan dirangkai dengan bambu utuh. Berdasarkan pada penelitian sebelumnya oleh Sagala et al. (2013), budidaya kepiting bakau dapat dilakukan dengan peletakkan wadah budidaya kurungan dasar, yaitu dengan model pen culture maupun singlet room. Pemasangan wadah budidaya atau karamba dengan letak kurung dasar dipasang pada perairan yang relatif dangkal.

Penentuan letak wadah budidaya harus mempertimbangkan faktor biologis kepiting bakau (S. serrata), sehingga dapat direkayasa agar sesuai dengan kelayakan lingkungan dan kebiasaan hidupnya, serta dapat meningkatkan pertumbuhan dan kelulushidupan kepiting bakau yang dibudidayakan. Oleh karena itu, maka perlu dilakukan penelitian tentang letak wadah budidaya kurung dasar dan kurung lepas dasar untuk mengetahui pengaruhnya terhadap pertumbuhan dan kelulushidupan kepiting bakau (S. serrata).

\section{METODE PENELITIAN}

\section{Materi}

Hewan uji yang digunakan adalah kepiting bakau (S. serrata) dengan bobot awal pemeliharaan \pm 80 g/ekor. Padat penebaran kepiting bakau dalam penelitian ini adalah 4 ekor/m² (Suryono et al., 2012). Jumlah kepiting yang digunakan dalam penelitian ini adalah 48 ekor. Hewan uji yang digunakan berasal dari pengepul atau nelayan di daerah Juwana, Pati, Jawa Tengah.

Pakan yang digunakan selama proses pemeliharaan kepiting bakau adalah pakan ikan runcah. Metode pemberian pakan yang digunakan adalah fix feeding rate dengan dosis pemberian pakan sebesar $10 \%$ dari bobot tubuh yang diberikan setiap 2 kali dalam sehari yaitu pagi $5 \%$ dan sore 5\% (Madyowati, 2011). Pakan tersebut berasal dari TPI yang berada di kota Rembang dan sekitarnya.

Wadah yang digunakan dalam penelitian ini adalah dengan menggunakan dua jenis karamba yang sama untuk dua 
peletakkan wadah budidaya yang berbeda, yaitu peletakkan kurung dasar (bottom) dan kurung lepas dasar (off bottom). Karamba dibuat dari bahan kayu dan bambu. Karamba tersebut berukuran $1 \mathrm{~m} \times 1 \mathrm{~m} \times$ 0,5m, setiap petak karamba diisi 4 ekor kepiting bakau. Bagian atas karamba di buat lubang atau pintu kecil yang dapat dibuka tutup untuk memudahkan pemberian pakan. Media pemeliharaan budidaya kepiting adalah berupa tambak dengan keketinggian air $\pm 70 \mathrm{~cm}$ dengan ukuran luas $10 \mathrm{~m} \times 18 \mathrm{~m}$.

\section{Metode}

Metode yang digunakan dalam penelitian ini adalah metode eksperimental. Metode eksperimental merupakan metode yang menerapkan suatu usaha terencana untuk mengungkapkan fakta-fakta baru atau menguatkan teori dan mengkritik hasil dari penelitian yang sudah ada. Metode ini dimaksudkan untuk mengetahui pengaruh perbedaan sistem wadah budidaya kurung dasar dan kurung apung terhadap pertumbuhan dan kelulushidupan kegiatan budidaya pembesaran kepiting bakau ( $S$. serrata). Menurut Surachmad (2002), metode eksperimen adalah metode dengan teknik pengumpulan data yang dilakukan secara observasi langsung terhadap gejalagejala subyek yang diamati.
Penelitian ini dikelompokkan berdasarkan perlakuannya, yaitu dengan menggunakan 2 perlakuan dan 6 ulangan, dengan tujuan untuk membandingkan sistem wadah budidaya letak kurung dasar dan letak kurung lepas dasar untuk mengetahui pengaruhnya terhadap pertumbuhan dan kelulushidupan kepiting bakau (S. serrata). Adapun perlakuan yang dilakukan dalam penelitian ini adalah sebagai berikut :

Perlakuan A : Karamba pemeliharaan dengan letak wadah kurung dasar (bottom)

Perlakuan B : Karamba pemeliharaan dengan letak wadah kurung lepas dasar (off bottom)

Alasan penggunaan perlakuan letak wadah budidaya kurung dasar adalah mengadaptasikan dari metode budidaya pen culture atau budidaya karamba tancap dasar, sedangkan perlakuan letak kurung lepas dasar mengadaptasikan dari metode budidaya karamba apung, dimana kedua metode tersebut merupakan yang biasa digunakan oleh pembudidaya kepiting bakau (S. serrata), sehingga diaplikasikan ke dalam suatu perlakuan pada penelitian untuk mengetahui pengaruh dari letak wadah budidaya kurung dasar dan kurung 
lepas dasar terhadap pertumbuhan dan kelulushidupan kepiting bakau (S.serrata).

Proses aklimatisasi dilakukan pada awal kegiatan sebelum dilakukan perlakuan terhadap hewan uji, pada penelitian ini diamati nilai pertambahan bobot mutlak, pertumbuhan relatif, serta perhitungan kelulushidupan, selain itu dilakukan juga pengamatan prosentase moulting (pergantian kulit) yang dilakukan setiap 3 hari sekali, dan pengukuran harian kualitas air selama masa pemeliharaan. Penelitian dilaksanakan selama 30 hari (1 bulan) yaitu pada 18 Juni sampai 18 Juli 2017. Bentuk penerapan letak wadah penelitian terhadap permukaan air dan substrat (tampak samping) dapat dilihat pada Gambar 1. sebagai berikut :

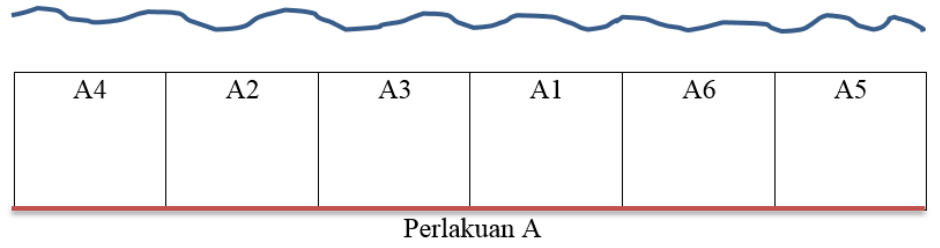

\begin{tabular}{|c|c|c|c|c|c|}
\hline B2 & B6 & B5 & B2 & B1 & B4 \\
\hline
\end{tabular}

Perlakuan B

Gambar 1. Tata letak wadah penelitian terhadap permukaan air dan substrat

Keterangan :

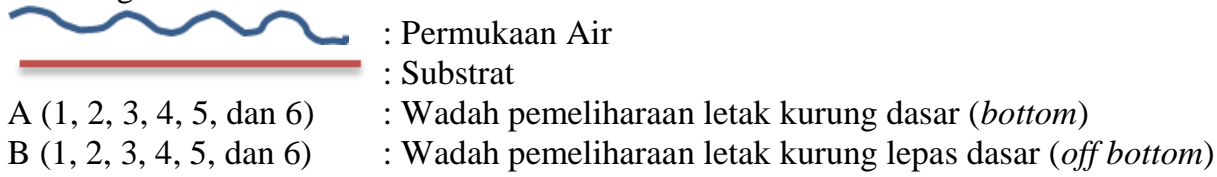

\section{Pengumpulan data}

Pengumpulan data yang dilakukan dalam penelitian ini meliputi data pertumbuhan bobot mutlak, laju $\begin{array}{lll}\text { pertumbuhan } & \text { relatif }\end{array}$ kelulushidupan (Survival Rate), prosentase moulting (pergantian kulit), dan data kualitas air.

\section{a. Pertumbuhan/pertambahan bobot mutlak}

Perhitungan nilai pertumbuhan/ pertambahan bobot mutlak kepiting bakau (S. serrata) dengan menggunakan rumus sebagai berikut (Effendie, 1997):

$$
\mathrm{W}=\mathrm{Wt}-\mathrm{Wo}
$$

Keterangan :

$\mathrm{W}=$ Pertumbuhan bobot mutlak $(\mathrm{g})$ 
$\mathrm{Wt}=$ Bobot hewan uji pada akhir penelitian $(\mathrm{g})$

Wo = Bobot hewan uji pada awal penelitian $(\mathrm{g})$

\section{b. Laju pertumbuhan relatif}

Menurut Takeuchi (1988), laju pertumbuhan relatif (Relative Growth Rate) ikan dihitung dengan menggunakan rumus:

$$
\mathrm{RGR}=\frac{\mathrm{W}_{\mathrm{t}}-\mathrm{W}_{\mathrm{o}}}{\mathrm{W}_{\mathrm{o}} \times \mathrm{t}} \times 100 \%
$$

Keterangan :

RGR = Laju pertumbuhan relatif $(\% /$ hari $)$

$\mathrm{W}_{\mathrm{t}}=$ Bobot total ikan pada akhir pemeliharaan $(\mathrm{g})$

$\mathrm{W}_{\mathrm{o}}=$ Bobot total ikan pada awal pemeliharaan $(\mathrm{g})$

$\mathrm{t}=$ Waktu pemeliharaan (hari)

\section{c. Kelulushidupan}

Menurut Effendie (1997), Survival Rate (SR) merupakan prosentase kelulushidupan ikan yang dapat dihitung dengan rumus sebagai berikut:

$$
\mathrm{SR}=\frac{\mathrm{N}_{\mathrm{t}}}{\mathrm{N}_{0}} \times 100 \%
$$

Keterangan :

$\mathrm{SR}=$ Tingkat kelulushidupan ikan $(\%)$
$\mathrm{N}_{\mathrm{t}}=$ Jumlah ikan pada akhir penelitian (ekor)

$\mathrm{N}_{0}=$ Jumlah ikan pada awal penelitian (ekor)

\section{d. Jumlah Kepiting Moulting}

Pengamatan pergantian kulit (moulting) kepiting bakau ( $S$. serrata) dilakukan selama masa pemeliharaan. Sampling pengamatan pergantian kulit dilakukan setiap 3 hari sekali dengan menghitung berapa kali kepiting yang ganti kulit (moulting) selama penelitian berlangsung, kemudian dihitung periodenya dalam dalam satuan waktu. Jumlah kepiting moulting dihitung berdasarkan pada perbandingan jumlah kepiting yang moulting dengan jumlah awal kepiting (Alamsyah dan Fujaya, 2010). Pengamatan tingkat moulting dengan mengamati kepiting satu per satu tiap basket.

\section{e. Kualitas air}

Pengecekan kualitas air pada media penelitian meliputi beberapa variabel diantaranya suhu, dan derajat keasaman $(\mathrm{pH})$ yang diukur setiap hari. Pengamatan kualitas air yang terdiri dari kandungan ammonia $\left(\mathrm{NH}_{3}\right)$, salinitas, dan kandungan 
oksigen terlarut (DO) dilakukan pada awal, tengah dan akhir penelitian.

\section{Analisa Data}

Data yang dianalisa secara statistik adalah pertambahan bobot mutlak, pertumbuhan relatif (RGR), dan kelulushidupan (SR). Data sebelumnya dianalisis terlebih dahulu menggunakan uji normalitas, uji homogenitas dan uji additivitas. Menurut Srigandono (1981), Analisis ragam dapat dilakukan, jika hasil ketiga uji tersebut menunjukkan bahwa data menyebar normal, homogen dan additiv, apabila diketahui terdapat perbedaan yang nyata maka dilakukan uji lanjut $\mathrm{T}$ tabel untuk mengetahui perbedaan nilai dari masing-masing perlakuan, sehingga dapat diperoleh hasil perlakuan yang terbaik. Analisa deskripsif digunakan untuk menjelaskan kelayakan kualitas air pada media pemeliharaan bagi kehidupan kepiting bakau selama penelitian, dengan membandingkan nilai kelayakan berdasarkan literatur (Hastuti et al., 2015).

\section{HASIL DAN PEMBAHASAN}

\section{a. Pertambahan Bobot Mutlak}

Berdasarkan

perhitungan

pertambahan bobot mutlak kepiting bakau
(S. serrata), diperoleh data pertambahan bobot mutlak yang tersaji pada Tabel 1 .

Tabel 1. Rata-Rata Pertambahan Bobot Mutlak (g) Kepiting Bakau (Scylla serrata)

\begin{tabular}{ccc}
\hline \multirow{2}{*}{ Ulangan } & \multicolumn{2}{c}{ Perlakuan } \\
\cline { 2 - 3 } & $\begin{array}{c}\text { Kurung } \\
\text { Dasar }\end{array}$ & $\begin{array}{c}\text { Kurung Lepas } \\
\text { Dasar }\end{array}$ \\
\hline 1 & 23,15 & 34,03 \\
2 & 21,77 & 31,27 \\
3 & 18,64 & 31,90 \\
4 & 31,70 & 26,98 \\
5 & 20,98 & 31,20 \\
6 & 21,77 & 28,43 \\
\hline Rerata+SD & $23,00 \pm 4,51$ & $30,63 \pm 2,53$
\end{tabular}

Uji normalitas, homogenitas dan additivitas dilakukan terhadap nilai pertambahan bobot mutlak kepiting bakau (S. serrata). Hasil uji menunjukkan bahwa data menyebar normal, secara homogenitas menunjukkan bahwa databersifat homogen dan secara additivitas menunjukkan bahwa data bersifat additiv, sehingga memenuhi syarat untuk dilanjutkan dengan uji T-test untuk mengetahui perbedaan signifikan antara letak wadah budidaya kurung dasar dan kurung lepas dasar. Hasil uji T-test pertambahan bobot mutlak kepiting bakau teraji pada Tabel 2 . 
Tabel 2. Analisis T test Pertambahan Bobot Mutlak Kepiting Bakau (Scylla serrata)

\begin{tabular}{lrr}
\hline & Kurung Dasar & $\begin{array}{c}\text { Kurung Lepas } \\
\text { Dasar }\end{array}$ \\
\hline Mean & 23,00166667 & 30,635 \\
Variance & 20,36565667 & 6,41395 \\
Observations & 6 & 6 \\
Pooled Variance & 13,38980333 & \\
Hypothesized & & \\
Mean Difference & 0 & \\
Df & 10 & \\
t Stat & $-3,613164677$ & \\
P(T<=t) one-tail & $0,002371568 *$ & \\
t Critical one-tail & 1,812461123 & \\
P(T<=t) two-tail & 0,004743136 & \\
t Critical two-tail & 2,228138852 & \\
\hline Keterangan : * p-value $<\alpha=0.05$ & $=$ berpengaruh \\
nyata &
\end{tabular}

Hasil analisis uji T-test pertambahan bobot mutlak menunjukkan bahwa nilai p-value pengujian adalah 0.0023, dengan menggunakan kaidah pengambilan keputusan berdasarkan p-value, maka pada $\alpha=0.05$ dapat disimpulkan bahwa pengujian menunjukkan tolak $\mathrm{H}_{0}$, sehingga dapat dijelaskan bahwa letak wadah budidaya kurung dasar dan kurung lepas dasar berpengaruh nyata terhadap pertambahan bobot mutak kepiting bakau (S. serrata). Berdasarkan nilai mean (ratarata) yang diperoleh pada hasil analisis uji T-test pada perlakuan letak kurung dasar dan letak kurung lepas dasar berurutan yaitu 23,001 dan 30,635. Hasil tersebut menunjukkan bahwa perlakuan letak kurung lepas dasar memberikan rata-rata yang lebih besar dari perlakuan letak kurung dasar, sehingga dapat dikatakan bahwa pertambahan bobot mutlak kepiting bakau (S. serrata) pada perlakuan letak kurung lepas dasar lebih baik dari perlakuan letak kurung dasar.

\section{b. Laju pertumbuhan relatif (Relative Growth Rate)}

Berdasarkan perhitungan laju pertumbuhan relatif (Relative Growth Rate) kepiting bakau (S. serrata), diperoleh data pertumbuhan relatif yang tersaji pada Tabel 3.

Tabel 3. Rata-Rata Laju Pertumbuhan Relatif (\% per hari) Kepiting Bakau (Scylla serrata)

\begin{tabular}{ccc}
\hline \multirow{2}{*}{ Ulangan } & \multicolumn{2}{c}{ Perlakuan } \\
\cline { 2 - 3 } & $\begin{array}{c}\text { Kurung } \\
\text { Dasar }\end{array}$ & $\begin{array}{c}\text { Kurung } \\
\text { Lepas } \\
\text { Dasar }\end{array}$ \\
\hline 1 & 1,01 & 1,28 \\
2 & 0,77 & 1,65 \\
3 & 0,85 & 1,16 \\
4 & 1,33 & 1,17 \\
5 & 0,81 & 1,24 \\
6 & 0,95 & 1,19 \\
\hline Rerata+SD & $0,95 \pm 0,20$ & $1,28 \pm 0,18$ \\
\hline
\end{tabular}

Hasil uji normalitas, homogenitas dan additivitas yang didapatkan terhadap nilai laju pertumbuhan relatif (Relative Growth Rate) kepiting bakau (S. serrata) menunjukkan bahwa data menyebar normal, bersifat homogen dan additiv, sehingga memenuhi syarat untuk dilanjutkan dengan uji $\mathrm{T}$ test untuk mengetahui perbedaan signifikan antara letak wadah budidaya kurung dasar dan kurung lepas dasar. Hasil anilisis uji T-Test 
laju pertumbuhan relatif (Relative Growth Rate) kepiting bakau teraji pada Tabel 4.

Hasil analisis uji T-test RGR menunjukkan bahwa nilai p-value pengujian adalah 0.0078, dengan menggunakan kaidah pengambilan keputusan berdasarkan p-value, maka pada $\alpha=0.05$ dapat disimpulkan bahwa pengujian menunjukkan tolak $\mathrm{H}_{0}$, sehingga dapat dijelaskan bahwa letak wadah budidaya kurung dasar dan kurung lepas dasar berpengaruh nyata terhadap laju pertumbuhan relatif kepiting bakau ( $S$. serrata).

Tabel 4. Analisis T-test Laju Pertumbuhan Relatif (Relative Growth Rate) Kepiting Bakau (Scylla serrata)

\begin{tabular}{lrr}
\hline & \multicolumn{2}{c}{ Kurung } \\
& Kurung Dasar & Lepas Dasar \\
\hline Mean & 0,953333333 & 1,281666667 \\
Variance & 0,041986667 & 0,034616667 \\
Observations & 6 & 6 \\
Pooled Variance & 0,038301667 & \\
Hypothesized & & \\
Mean Difference & 0 & \\
Df & 10 & \\
t Stat & $-2,905807009$ & \\
P(T<=t) one-tail & $0,007838449 *$ & \\
t Critical one-tail & 1,812461123 & \\
P(T<=t) two-tail & 0,015676897 & \\
t Critical two-tail & 2,228138852 & \\
\hline Keterangan : & & \\
\hline
\end{tabular}

Keterangan : $*=$ p-value $<\alpha=0.05=$ berpengaruh nyata

Berdasarkan nilai mean (rata-rata) yang diperoleh pada hasil analisis uji T-test pada perlakuan A (letak kurung dasar) dan B (letak kurung lepas dasar) berurutan yaitu 0,953 dan 1,281, hasil tersebut menunjukkan bahwa perlakuan letak kurung lepas dasar memberikan rata-rata yang lebih besar dari perlakuan letak kurung dasar, sehingga dapat dikatakan bahwa laju pertumbuhan kepiting bakau ( $S$. serrata) pada perlakuan letak kurung lepas dasar lebih baik dari perlakuan letak kurung dasar.

\section{c. Kelulushidupan (Survival Rate)}

Berdasarkan perhitungan kelulushidupan kepiting bakau (S. serrata), diperoleh data kelulushidupan yang tersaji pada Tabel 5.

Tabel 5. Rata-Rata Kelulushidupan Kepiting Bakau (Scylla serrata)

\begin{tabular}{ccc}
\hline Ulangan & \multicolumn{2}{c}{ Survivar Rate (\%) } \\
\cline { 2 - 3 } & $\begin{array}{c}\text { Kurung } \\
\text { Dasar }(\%)\end{array}$ & $\begin{array}{c}\text { Kurung Lepas } \\
\text { Dasar }(\%)\end{array}$ \\
\hline 1 & 50 & 100 \\
2 & 75 & 75 \\
3 & 100 & 100 \\
4 & 50 & 100 \\
5 & 100 & 75 \\
\hline 6 & 75 & 75 \\
\hline Rerata+SD & $75,00 \pm 22,36$ & $87,50 \pm 13,69$ \\
\hline
\end{tabular}

Uji normalitas, homogenitas dan additivitas dilakukan terhadap nilai kelulushidupan kepiting bakau (S. serrata). Hasil uji menunjukkan bahwa data menyebar normal, secara homogenitas menunjukkan bahwa data bersifat homogen dan secara additivas menunjukkan bahwa data bersifat additiv, sehingga memenuhi syarat untuk 
dilanjutkan dengan uji $\mathrm{T}$ test untuk mengetahui perbedaan signifikan antara letak wadah budidaya kurung dasar dan kurung lepas dasar. Hasil anilisis uji T-test kelulushidupan kepiting bakau teraji pada Tabel 6.

Tabel 6. Analisis Uji T-test Kelulushidupan Kepiting Bakau (Scylla serrata)

\begin{tabular}{lrr}
\hline & $\begin{array}{r}\text { Kurung } \\
\text { Dasar }\end{array}$ & $\begin{array}{r}\text { Kurung } \\
\text { Lepas } \\
\text { Dasar }\end{array}$ \\
\hline Mean & 75 & 87,5 \\
Variance & 750 & 187,5 \\
Observations & 6 & 6 \\
Pooled Variance & 468,75 & \\
Hypothesized & & \\
Mean Difference & 0 & \\
Df & 10 & \\
t Stat & -1 & \\
P(T<=t) one-tail & 0,170446566 & \\
t Critical one-tail & 1,812461123 & \\
P(T<=t) two-tail & 0,340893132 & \\
t Critical two-tail & 2,228138852 & \\
\hline
\end{tabular}

Hasil analisis uji T-test kelulushidupan menunjukkan bahwa nilai p-value pengujian adalah 0.1704 , dengan menggunakan kaidah pengambilan keputusan berdasarkan p-value, maka pada $\alpha=0.05$ dapat didinyatakan bahwa pengujian menunjukkan terima $\mathrm{H}_{0}$, sehingga dapat dijelaskan bahwa letak wadah budidaya kurung dasar dan kurung lepas dasar tidak berpengaruh nyata terhadap kelulushidupan kepiting bakau ( $S$. serrata).

\section{d. Jumlah Kepiting moulting}

Berdasarkan perhitungan prosentase moulting pada kepiting bakau ( $S$. serrata), diperoleh data hasil prosentase moulting yang tersaji pada tabel 7 .

Tabel 7. Jumlah moulting (ekor) Kepiting Bakau

\begin{tabular}{ccc}
\multicolumn{3}{c}{ Scylla serrata) } \\
$\begin{array}{c}\text { Minggu } \\
\text { ke }\end{array}$ & $\begin{array}{c}\text { Moulting Kepiting } \\
\text { Kurung } \\
\text { Dasar }\end{array}$ & $\begin{array}{c}\text { Kurung } \\
\text { Lepas } \\
\text { Dasar }\end{array}$ \\
\hline 1 & 0 & 0 \\
2 & 0 & 1 \\
3 & 3 & 11 \\
4 & 5 & 2 \\
\hline Jumlah & 8 & 14 \\
\hline
\end{tabular}

Hasil penelitian menunjukkan moulting terjadi setelah minggu pertama, pada perlakuan letak kurung dasar mencapai puncak pada minggu ke empat, sedangkan pada perlakuan kurung lepas dasar mencapai puncak pada minggu ke tiga masa pemeliharaan. Jumlah kepiting moulting yang tertinggi terjadi pada wadah budidaya dengan letak kurung lepas dasar yaitu sebanyak 14 ekor.

\section{e. Kualitas air}

Kualitas air merupakan data pendukung dari kegiatan penelitian yang dilakukan. Parameter kualitas air yang diukur selama penelitian meliputi: suhu, oksigen terlarut (DO), salinitas, keasaman air $(\mathrm{pH})$, dan amonia $\left(\mathrm{NH}_{3}\right)$. Berdasarkan 
hasil penelitian, kisaran kualitas air selama masa pemeliharaan tersaji pada Tabel 10 .

Tabel 10. Kualitas Air Wadah Budidaya Kepiting Bakau (Scylla serrata)

\begin{tabular}{|c|c|c|c|c|}
\hline \multirow{2}{*}{ Variabel } & \multicolumn{2}{|c|}{ Kisaran } & \multirow{2}{*}{ Kelayakan } & \multirow{2}{*}{$\begin{array}{l}\text { Pustaka } \\
\text { (tahun) }\end{array}$} \\
\hline & A & $\mathrm{B}$ & & \\
\hline $\begin{array}{l}\text { Suhu } \\
\left({ }^{\circ} \mathrm{C}\right)\end{array}$ & $28-30$ & $29-30$ & $25-35$ & $\begin{array}{l}\text { Hastuti } \\
\text { et al. } \\
\text { (2015) }\end{array}$ \\
\hline $\begin{array}{l}\text { DO } \\
(\mathrm{mg} / \mathrm{L})\end{array}$ & $\begin{array}{l}3,14- \\
3,85\end{array}$ & $\begin{array}{l}3,63- \\
4,28\end{array}$ & $>3$ & $\begin{array}{l}\text { Cheng et } \\
\text { al. } \\
(2003)\end{array}$ \\
\hline $\begin{array}{l}\text { Salinitas } \\
\text { (ppt) }\end{array}$ & $29-31$ & $29-31$ & $15-35$ & $\begin{array}{l}\text { Hastuti } \\
\text { et al. } \\
\text { (2015) }\end{array}$ \\
\hline $\mathrm{pH}$ & 7-9 & 7-9 & $7,0-9,0$ & $\begin{array}{l}\text { Hastuti } \\
\text { et al. } \\
\text { (2015) }\end{array}$ \\
\hline $\begin{array}{l}\text { Amonia } \\
(\mathrm{mg} / \mathrm{L})\end{array}$ & $\begin{array}{l}0,47- \\
0,77\end{array}$ & $\begin{array}{l}0,27- \\
0,57\end{array}$ & $<1,0$ & $\begin{array}{l}\text { Fujaya } e t \\
\text { al. } \\
(2012)\end{array}$ \\
\hline
\end{tabular}

Hasil pengukuran parameter kualitas air menunjukkan bahwa kualitas air selama masa penelitian masih berada pada kisaran batas kelayakan untuk budidaya kepiting bakau (S. serrata), sehingga dapat dikatakan bahwa selama masa pemaliharaan kultivan berada pada kondisi lingkungan yang layak.

\section{Pembahasan}

Berdasarkan penelitian yang telah dilakukan, pertumbuhan kepiting bakau ( $S$. serrata) dapat digambarkan dengan menganalisis variabel pertambahan bobot mutlak dan laju pertumbuhan relatif. Pertambahan bobot mutlak merupakan pertambahan bobot individu kepiting yang dihitung dari awal penebaran sampai dengan berat kepiting ketika dilakukan pemanenan. Berdasarkan hasil yang didapatkan pada penelitian ini, pertambahan bobot mutlak pada perlakuan letak kurung lepas dasar memberikan ratarata pertambahan bobot mutlak yang lebih tinggi dari perlakuan letak kurung dasar. Rata-rata yang diperoleh pada perlakuan letak kurung dasar yaitu sebesar 23,00 g, sedangkan pada perlakuan letak kurung lepas dasar yaitu sebesar 30,64 g. Berdasarkan hasil tersebut, menunjukkan bahwa budidaya kepiting bakau dengan letak wadah budidaya kurung lepas dasar memberikan pertambahan bobot mutlak yang lebih baik untuk kepiting bakau $(S$. serrata) dibandingkan dengan letak wadah budidaya kurung dasar. Berdasarkan hasil yang didapatkan pada penelitian ini, laju pertumbuhan relatif pada perlakuan B dengan letak wadah budidaya kurung lepas dasar memberikan rata-rata pertambahan bobot mutlak yang lebih tinggi dari perlakuan B. Rata-rata pertumbuhan relatif yang diperoleh pada perlakuan A yaitu sebesar $0,95 \mathrm{~g}$, sedangkan pada perlakuan B yaitu sebesar 1,28 g. Berdasarkan hasil tersebut, menunjukkan bahwa budidaya kepiting bakau dengan letak wadah 
budidaya kurung lepas dasar memberikan laju pertumbuhan relatif yang lebih baik untuk kepiting bakau (S. serrata) dibandingkan dengan letak wadah budidaya kurung dasar.

Berdasarkan analisa secara deskriptif, nilai pertambahan bobot mutlak dan laju pertumbuhan relatif yang didapatkan pada kedua perlakuan diduga di pengaruhi oleh perbedaan ruang gerak dari kepiting bakau (S. serrata), pada letak wadah budidaya kurung lepas dasar kepiting bakau mempunyai ruang gerak yang lebih sedikit dibandingkan dengan kurung dasar, hal tersebut dikarenakan pada wadah kurung lepas dasar wadah karamba tidak tenggelam secara keseluruhan melainkan hanya setengahnya saja, sedangkan pada letak kurung dasar karamba tenggelam secara keseluruhan. Kepiting bakau mempunyai sifat sering berenang pasif pada kolom perairan, berkaitan dengan hal ini diduga menyebabkan kepiting pada perlakuan kurung lepas dasar mempunyai ruang gerak yang lebih sedikit sehingga energi yang digunakan kepiting untuk bergerak lebih sedikit dan lebih banyak memanfaatkan energi untuk pertumbuhan dibandingkan dengan kepiting pada letak wadah budidaya kurung dasar. Hal tersebut diperkuat oleh Glencross (2008), menyatakan bahwa keberhasilan kegiatan budidaya kepiting, terutama kegiatan pembesaran dapat dilihat dari produksi kepiting yang ditunjukkan oleh pertumbuhan yang pesat dalam waktu singkat dan kelulushidupan yang tinggi, secara fisiologis pertumbuhan hanya dapat terjadi apabila terdapat kelebihan energi, setelah energi melalui pakan yang dikonsumsi dikurangi dengan kebutuhan energi untuk berbagai aktivitas. Menurut pendapat Karim (2005), menyatakan bahwa adanya pertumbuhan kepiting dapat terjadi apabila energi yang diretensi positif atau energi yang disimpan lebih besar dibandingkan dengan energi yang digunakan untuk aktivitas tubuh. Kepiting memperoleh energi melalui pakan yang dikonsumsi dan pembelanjaannya digunakan untuk berbagai aktivitas termasuk aktivitas untuk bergerak dan berenang.

Faktor lain yang mempengaruhi hasil pada pertambahan bobot mutlak dan laju pertumbuhan harian diduga karena pada wadah budidaya kepiting bakau dengan letak kurung lepas dasar relatif mempunyai kualitas air yang lebih baik, yaitu pada variabel kandungan oksigen terlarut (DO), suhu, dan kandungan amonia. Hal tersebut 
dibuktikan dengan kisaran kandungan DO, suhu, dan amonia pada perlakuan A (letak kurung dasar) dan B (letak kurung lepas dasar) berurutan yaitu sebesar 3,14-3,85 $\mathrm{mg} / \mathrm{L}$ dan 3,63-4,28 mg/L, kisaran suhu sebesar $28-30^{\circ} \mathrm{C}$ dan $29-30^{\circ} \mathrm{C}$, serta kisaran amonia yaitu 0,47-0,77 $\mathrm{mg} / \mathrm{L}$ dan 0,27-0,57 mg/L. Menurut Adha (2015), menyatakan bahwa salah satu faktor yang mempengaruhi kelulushidupan kepiting bakau adalah kualitas air. Air merupakan hal yang penting bagi kehidupan kepiting bakau karena secara langsung menjadi kebutuhan kepiting bakau, yaitu sebagai habitat hidup. Air merupakan komponen abiotik yang memiliki berbagai kondisi kualitas. Kondisi kualitas air yang berbeda dapat mengakibatkan dampak yang berbeda pada pertumbuhan dan perkembangan kepiting bakau. Kisaran nilai kelayakan suhu yang baik menurut Hastuti et al., (2015) adalah $25-30^{\circ} \mathrm{C}$. Perbedaan nilai suhu pada kedua perlakuan diduga berpengaruh terhadap metabolisme dari kepiting bakau ( $S$. serrata) sehingga akan berpengaruh juga terhadap laju pertumbuhan relatif yang didapatkan. Suhu air pada media budidaya akan mempengaruhi sistem metabolisme dari kepiting bakau (S. serrata), semakin tinggi suhu perairan, maka akan meningkatkan metabolisme dari kultivan, begitu pula sebaliknya, pada suhu yang lebih rendah, maka sistem metabolisme tubuh dari organisme juga relatif menurun. Hal tersebut diperkuat oleh Adha (2015), menyatakan bahwa suhu air mempengaruhi pertumbuhan, aktivitas moulting (ganti kulit) dan nafsu makan kepiting bakau. Suhu air yang lebih rendah dari $20^{\circ} \mathrm{C}$ dapat mengakibatkan aktivitas dan nafsu makan turun drastis. Suhu terlalu tinggi juga tidak dapat di toleransi kepiting bakau. Menurut Karim et al. (2015), pada suhu yang lebih rendah perkembangan kepiting menjadi lambat dan perkembangan menjadi lebih lama, apabila hal tersebut berlangsung maka proses metabolisme berjalan lambat sehingga proses-proses fisiologis dalam tubuh akan terganggu, kondisi ini dapat mengakibatkan sebagian besar energi yang tersimpan dalam tubuh kepiting digunakan untuk penyesuian diri terhadap lingkungan yang kurang mendukung tersebut, sehingga dapat merusak sistem metabolisme atau pertukaran zat. Kisaran variabel oksigen terlarut (Dissolved Oxygen) pada perlakuan letak kurung lepas dasar lebih tinggi dibandingkan perlakuan letak kurung dasar. Perbedaan nilai oksigen terlarut akan sangat berpengaruh terhadap pertambahan bobot mutlak pada kepiting 
bakau (S. serrata). Menurut Cheng et al. (2003), kisaran kelayakan DO pada budidaya kepiting adalah $>3 \mathrm{mg} / \mathrm{L}$. Hal tersebut berkaitan dengan laju metabolisme dan sistem respirasi dari kepiting bakau, dengan meningkatnya oksigen dalam sistem metabolisme, maka akan memicu kepiting untuk tumbuh. Oksigen pada sistem metabolisme tubuh dibutuhkan dalam proses respirasi. Hal tersebut diperkuat oleh Salmin (2005), menyatakan bahwa oksigen terlarut dibutuhkan oleh organisme untuk pernapasan, proses metabolisme atau pertukaran zat yang kemudian menghasilkan energi untuk pertumbuhan dan pembiakan. Kisaran kandungan amonia $\left(\mathrm{NH}_{3}\right)$ yang diukur pada perlakuan letak kurung lepas dasar mempunyai nilai yang lebih baik dibandingkan perlakuan letak kurung dasar, walaupun pada kedua media kandungan amonia masih dalam kelayakan, akan tetapi adanya perbedaan pada kedua wadah akan berpengaruh terhadap metabolisme kepiting. Menurut Fujaya (2012), kelayakan kandungan amonia untuk budidaya kepiting adalah $<1,0 \mathrm{mg} / \mathrm{L}$. Sumber amonia yang terdapat dalam wadah budidaya salah satunya yaitu berasal dari pembuangan sisa pencernaan dari kepiting bakau, pada perlakuan letak kurung dasar nilai amonia relatif lebih tinggi, hal tersebut disebabkan karena zat sisa yang dihasilkan dari pencernaan terkumpul di dasar karamba, sedangkan pada perlakuan letak kurung lepas dasar zat-zat sisa tersebut tidak terkumpul di dasar karamba, akan tetapi jatuh ke dasar perairan. Hal tersebut diperkuat dalam Alamsyah dan Fujaya (2010), menyatakan bahwa protein merupakan zat terpenting dari semua zat gizi yang diperlukan, karena merupakan zat penyusun dan sumber energi utama, penggunaan protein yang tinggi sebagai sumber energi menyebabkan kelebihan nitrogen akan dibuang dalam bentuk amonia melalui sistem ekskresi. Berdasarkan hal tersebut dapat dinyatakan bahwa diduga faktor kualitas air yang berbeda pada kedua perlakuan yang berperan besar mempengaruhi perbedaan hasil nilai pertambahan bobot mutlak dan pertumbuhan relatif dari kepiting bakau yang dipelihara, walaupun perbedaan tersebut tidak terlalu signifikan, akan tetapi jika terjadi dalam waktu yang relatif lama maka akan mempengaruhi kondisi fisiologis dari kepiting bakau, sehingga dapat mempengaruhi laju metabolisme dari masing-masing individu kepiting bakau yang dibudidayakan serta berpengaruh juga terhadap pertumbuhan yang dihasilkan 
Kelulushidupan

merupakan

parameter keberhasilan suatu usaha budidaya, jika nilai kelulushidupan kultivan yang dibudidayakan tinggi, maka dapat dikatakan bahwa budidaya tersebut adalah berhasil. Berdasarkan hasil penelitian, perbedaan letak wadah budidaya kurung dasar dan kurung lepas dasar tidak berpengaruh nyata terhadap kelulushidupan kepiting bakau (S. serrata). Terdapat beberapa faktor yang dapat mempengaruhi kululushidupan pada budidaya kepiting bakau seperti faktor penyesuaian lingkungan (adaptasi), keadaan lingkungan budidaya, agensia penyakit, serta sifat kanibalisme yang dimiliki kepiting bakau (S. serrata). Menurut Karim et al. (2015), menyatakan bahwa tingkat kelulushidupan kepiting yang dihasilkan umumnya masih rendah dan belum stabil. Beberapa faktor yang diduga menjadi penyebab terjadinya kematian pada kepiting diantaranya akibat lingkungan pemeliharaan yang tidak optimum dan kualitas pakan yang rendah, sehingga untuk menghasilkan kelulushidupan kepiting bakau yang maksimal, maka lingkungan pemeliharaan harus berada pada kisaran optimal serta pakan yang berkualitas. Berdasarkan hasil penelitian, nilai kelulushidupan yang diperoleh pada kedua perlakuan A (letak kurung dasar) dan B (letak kurung lepas dasar) berurutan adalah $75,00 \pm 22,36 \%$ dan $87,50 \pm 13,69 \%$, setelah dilakukan uji $\mathrm{T}$ tabel, dinyatakan bahwa perbedaan letak wadah budidaya kurung dasar dan kurung lepas dasar tidak berpengaruh nyata terhadap kelulushidupan kepiting bakau. Hal tersebut diduga disebabkan oleh faktor lingkungan, dalam hal ini adalah kualitas air. Faktor eksternal seperti kualitas air pada kegiatan budidaya merupakan salah satu faktor kritis yang dapat mempengaruhi kelulushidupan kepiting bakau (S. serrata). Kualitas air pada kedua perlakuan dalam penelitian ini relatif baik dan masih sesuai dengan kelayakan hidup untuk kepiting bakau (S. serrata). Diduga hal tersebutlah yang menyebabkan antara kedua perlakuan tidak berpengaruh nyata terhadap kelulushidupan, walaupun terdapat fluktuasi, akan tetapi kepiting bakau masih dapat mentoleransi fluktuasi tersebut karena masih dalam ambang batas kelayakan hidup kepiting bakau ( $S$. serrata). Menurut Aditya et al. (2012), kualitas air merupakan salah satu faktor eksternal yang memegang peran penting yang berpengaruh pada keberhasilan proses budidaya pada umumnya baik secara langsung maupun tidak langsung. 


\section{KESIMPULAN DAN SARAN}

\section{Kesimpulan}

1. Letak wadah budidaya kurung lepas dasar berpengaruh nyata terhadap pertambahan bobot mutlak dan pertumbuhan relatif, namun tidak berpengaruh nyata terhadap kelulushidupan kepiting bakau ( $S$. serrata).

2. Letak wadah budidaya kurung lepas dasar memberikan pertumbuhan yang lebih baik untuk kepiting bakau dibandingkan dengan letak wadah budidaya kurung dasar dengan nilai pertumbuhan bobot mutlak dan laju pertumbuhan relatif berurutan yaitu $30,63 \pm 2,53 \mathrm{~g}$ dan $1,28 \pm 0,18 \%$ per hari.

\section{Saran}

1. Disarankan kepada pembudidaya kepiting bakau (S. serrata) untuk menerapkan letak wadah budidaya kurung lepas dasar dikarenakan menghasilkan pertumbuhan yang lebih baik.

2. Berdasarkan hasil penelitian ini, terdapat suatu batasan yaitu letak wadah budidaya pada penelitian ini hanya diterapkan pada lokasi budidaya yang tidak terpengaruh oleh pasang surut.

\section{UCAPAN TERIMA KASIH}

Terima kasih penulis ucapkan kepada Bapak Haji Jamari yang telah menyediakan tempat untuk penelitian saya, orang tua yang telah memberikan dukungan secara moral dan finansial, serta semua pihak yang telah mendukung saya untuk dapat melakukan penelitian tentang pengaruh perbedaan letak wadah budidaya kurung dasar dan kurung lepas dasar terhadap pertumbuhan dan kelulushidupan kepiting bakau (Scylla serrata).

\section{DAFTAR PUSTAKA}

Adha, M. 2015. Analisis Kelimpahan Kepiting Bakau (Scylla spp.) di Kawasan nangrove Dukuh Senik, Desa Bendono, Kecamatan Sayung, Kabupaten Demak. [Skripsi]. Jurusan Pendidikan Biologi. Universitas Walisongo Semarang. $74 \mathrm{hlm}$.

Aditya, B. P. dan S.A. Djunaedi. 2012. Pemberian Pellet dengan Ukuran Berbeda Terhadap Pertumbuhan Kepiting Bakau (Scylla serrata Forskal, 1755). Journal of Marine Research, 1(1) : 146 152.

Alamsyah, S. dan Y. Fujaya. 2010. Stimulasi Molting dan Pertumbuhan Kepiting Bakau (Scylla sp.) Melalui Aplikasi Pakan Buatan Berbahan Dasar Limbah Pangan yang Diperkaya dengan Ekstrak Bayam. Ilmu Kelautan, 15(3) : 170-178. 
Cheng, W., C.H. Liu and C.M. Kuo. 2003. Effect of dissolved oxygenon haemolymph parameters of freshwater giant prawn Macrobrachium rosenbergii (de Man). Aquaculture, 220: 843856.

Djunaedi, A., Sunaryo dan B.P. Aditya. 2015. Pertumbuhan Kepiting Bakau (Scilla serrata Forsskal, 1775) dengan Ukuran Pakan Berbeda pada Budidaya dengan Sistem Baterai. Jurnal Kelautan Tropis, 18(1): $46-51$.

Effendie, M.I. 1997. Biologi Perikanan. Yayasan Pustaka Nusantara. Yogyakarta. $163 \mathrm{hlm}$.

Fujaya, Y., S. Aslamsyah, L. Fudjaja dan N. Alam. 2012. Budidaya dan Bisnis Kepiting Lunak Stimulasi Moulting Dengan Ekstrak Bayam. Brilian Internasional. Surabaya. $114 \mathrm{hlm}$.

Glencross, B.D. 2008. A factorial growth and feed utilization model for barramundi Lates calcarifer based on Australian production conditions. Aquaculture Nutrition 14: 360-373.

Hastuti, Y.P., A. Ridwan, M.D. Safrina, K. Faturrohman, W. Nurussalam. 2015. Salinitas Optimum untuk Pertumbuhan Benih Kepiting Bakau Scylla serrata dalam Sistem Resirkulasi. Jurnal Akuakultur Indonesia, 14(1): 50 -57 .

Karim, M.Y. 2005. Kinerja Pertumbuhan Kepiting Bakau Betina (Scylla serata Forskal) pada Berbagi Salinitas Media dan Evaluasi pada Salinitas Optimum dengan
Kadar Protein Pakan Berbeda. [Desertasi]. Institut Pertanian Bogor.

Karim, M.Y., Zainuddin dan S. Aslamyah. 2015. Pengaruh Suhu terhadap Kelangsungan Hidup dan Percepatan Metamorfosis Larva Kepiting Bakau (Scylla serrata). Jurnal Perikanan., 17(2): 84 89.

Madyowati, S.O. 2011. Respon Pertumbuhan Kepiting Bakau (Scylla serrata Forskal) Terhadap Salinitas Dan Jenis Pakan Segar. Jurnal Kelautan, 17(1) : 1-6.

Rangka, N.A. 2007. Status Usaha Kepiting Bakau Ditinjau dari Aspek Peluang dan Prospeknya. Jurnal Neptunus., 14(1) : 90-100.

Sagala, L. S. S., M. Idris. dan M. N. Ibrahim. 2013. Perbandingan Pertumbuhan Kepiting Bakau (Scylla serrata) Jantan dan Betina pada Metode Kurungan Dasar. Jurnal Mina Laut Indonesia, 3(12): 46-54.

Salmin. 2005. Oksigen Terlarut (DO) dan Kebutuhan Oksigen Biologi (BOD) sebagai Salah Satu Indikator Untuk Menentukan Kualitas Perairan. Jurnal Oseana, (30)3 : 21-26.

Srigandono, B. 1981. Rancangan Percobaan Experimental Design. Universitas Diponegoro, Semarang, $140 \mathrm{hlm}$.

Surachmad, W. 2002. Penelitian Ilmiah Dasar. Metode dan Teknik. Edisi ke Tujuh.Tarsito. Bandung. 338 hlm. 
Suryono, C.A., Irwani dan B. Rochaddi. 2012. Pertambahan Biomasa Kepiting Bakau scylla serrata pada Daerah Mangrove dan Tidak Bermangrove. Jurnal Kelautan Tropis, 19(1): $76-80$. 